\title{
Antibacterial activity of the sea cucumber Holothuria leucospilota whole body extract against Staphylococcus aureus strains MRSA, SEA, and SEB
}

Noushin Arfatahery ( $\square$ arfa.n@fu-berlin.de)

Institut für Biologie, Freie Universität Berlin

Mohammad M. Khabbazan

Berlin University of Technology (TU Berlin)

\section{Research Article}

Keywords: Sea cucumber, Antimicrobial activity, Staphylococcus aureus

Posted Date: March 30th, 2021

DOI: https://doi.org/10.21203/rs.3.rs-301584/v1

License: (c) (i) This work is licensed under a Creative Commons Attribution 4.0 International License.

Read Full License 


\section{Abstract}

Aquatic organisms are a source of organic compounds that hold various features such as medical and nutritional activities. Within the framework of an antimicrobial activity study of marine macro-organisms from the Persian Gulf, bioactive compounds of the sea cucumber Holothuria leucospilota were extracted from the whole body using chloroform and methanol. The extracts were evaluated for their antibacterial effects against methicillin-resistant (MRSA) and staphylococcal enterotoxins producing (SEA, SEB) Staphylococcus aureus strains. Activities have been determined using three methods: disk diffusion tests, minimum bactericidal concentration (MBC), and minimum inhibitory concentration (MIC). The results demonstrate that methanol and chloroform extracts have an inhibitory effect on the growth of all strains at MIC concentrations up to $100 \mathrm{mg} / \mathrm{ml}$. Also, chloroform extracts demonstrate bactericidal activity against SEB in concentrations of about $100 \mathrm{mg} / \mathrm{ml}$. The extracts also show bactericidal effects against MRSA and SEB below $100 \mathrm{mg} / \mathrm{ml}$ concentrations. The highest antibacterial activity was found in methanol extract. Therefore, sea cucumber extracts are good candidates for the identification of new antimicrobials. Yet, comprehensive investigations are needed to separate and identify the active components for Holothuria leucospilota from the Persian Gulf.

\section{Introduction}

Analysis of utilizing natural aquatic products as pharmaceutical agents has been firmly growing. The biodiversity of the marine ecosystem surpasses that of the terrestrial ecosystem [1]. Sea cucumbers, echinoderms from the Holothuroidea class, are slow-moving, primarily nocturnal and benthic invertebrates. They have also been an essential source of food and used in traditional medicine, especially in some parts of Asia [2]. They have a noble profile of bioactive molecules, and the therapeutic potential of screening for anti-cancer [2], anti-tumor and anti-angiogenic [3, 4] antimicrobial, and antioxidant compounds [5] have been determined. Interesting bioactive compounds include lectins, sterols, peptides, cerebrosides, glycoprotein, glycosaminoglycan, glycosphingolipids, sulfated polysaccharides, and essential fatty acids $[6,7]$.

The Persian Gulf is a unique environment rich in biodiversity in the Middle East [8]. Holothuria leucospilota, ordinarily known as the Black tarzan or black sea cucumber, is the most frequently harvested sea cucumber in the Persian Gulf, with harvesting starting in 2004 at Qeshm Island [9]. $H$. leucospilota primarily generates bioactive secondary metabolites making it attractive for drug discovery [2]. Because of the increasing need for food and medicine applications, sea cucumbers have been exceedingly used $[10,11]$. But as sea cucumbers are not common around the Persian Gulf, out of nearly 1400 globally-recorded articles concerning Holothurian species [8, 9], only about 20 articles investigated Holothurian species in Iran [8]. Thus, there is still the opportunity for scrutinizing the biological and antimicrobial activity of sea cucumber breed in this region [12].

Previous studies demonstrated mild antibacterial efficacy of Holothurian compounds under very high concentrations $[13,14]$. For example, extracts from various organs or tissues of the sea cucumber 
Holothuria displayed limited bacteriostatic activity against when tested with methanol, chloroform, and nhexane eludes against human pathogens [15]. Compared with conventional antimicrobials, purified Holothurian peptides employed as antibacterial agents displayed relatively weak effectiveness [16]. Besides, though, protein hydrolysates of sea cucumbers are considered as a healthy and reliable substitute for artificial food preservatives $[16,17]$.

In this study, we demonstrate the antibacterial characteristic of methanol compared to chloroform extracts from the whole body of the $H$. leucospilota on Staphylococci producing enterotoxins (SEA, SEB) and Methicillin-resistant Staphylococcus aureus (MRSA). The activity is determined by using disc diffusion tests, MIC, and MBC using micro dilution.

\section{Materials And Methods}

\subsection{Sample collection}

We picked the samples of the sea cucumber H. leucospilota in March and May 2017 from the Persian Gulf. We used the scale method to identify the samples according to the Food and Agriculture Organization of the United Nations (FAO)[16]. All samples were maintained at $-20^{\circ} \mathrm{C}$ until used.

\subsection{Extraction and isolation of the samples}

Following Mamelona et al. (XXX) method, we extracted the bioactive compounds based on their polarity using water and organic solvents [16]. After defrosting $H$. leucospilota, they were cleaned with fresh water and cut from their anus into their mouth [16]. The whole bodies were opened, split into several pieces, and then kept at $+45^{\circ} \mathrm{C}$ for two days to completely dry. Next, the dehydrated samples were crushed using a grinder (WordStar) and were powdered thoroughly. The powder was extracted using a soxhlet extractor with either chloroform or methanol as solvents (Merck, Darmstadt, Germany) for 6 hours [17]. Then, following Estrada et al. (2000), we evaporated the solvents under vacuum conditions [18]. Finally, the extracts were freeze-dried to completely remove solvents and to create a solid form with increased purity [18].

\subsection{Antibacterial assay}

All staphylococcal samples (MRSA, SEA, and SEB) were tested with suspensions equivalent to 0.5 McFarlands [19]. S. aureus ATCC 25923 and S. aureus ATCC 29213 were applied in experiments, respectively, as a negative and positive control [20]. Then the samples were cultured on HIB and incubated at $37^{\circ} \mathrm{C}$ for $6 \mathrm{~h}$. Various extracts of the whole body were assayed against disk diffusion [19]. The disk diffusion method is commonly used for antimicrobial susceptibility of S.aureus $[19,20]$. Keeping the overall concentration at $100 \mathrm{mg} / \mathrm{ml}$, we added 40 microliters of methanol extracts to 40 microliters of chloroform on a blank disk. Positive controls were Vancomycin and Clindamycin antibiotics which were incubated at $37^{\circ} \mathrm{C}$ for $24 \mathrm{~h}$ to measure the zone of inhibitions. Then, the antimicrobial activity of $H$. leucospilota extracts was evaluated against MRSA, SEA, and SEB by the minimum bactericidal concentration (MBC) and minimum inhibitory concentration (MIC) methods [21, 22]. In our study, the extracts' optical density (OD) was read at zero, 4 h, 8 h, 12 h, and $24 \mathrm{~h}$ using an ELISA reader at $650 \mathrm{~nm}$. 
In case that the OD was decreased, it indicates that the extracts had an inhibitory effect on bacterial growth [21]. Samples in the multi-well plates that did not increase in OD after $24 \mathrm{~h}$ were examined for MBC [21]. All experiments were run in triplicate.

\subsection{Statistical analysis}

SPSS 19.0 (IBM, SPSS) was used for the analysis of variance of the raw data. Using Duncan's multiple range tests in ANOVA, we report all data as mean \pm SD. We also perform the least significant difference (LSD) tests to compare results among multiple groups.

\section{Results}

The results of the antibacterial assays using the methanol and chloroform extracts from the whole body of $H$. leucospilota against staphylococcal MRSA, SEA, and SEB are shown in Table 1. The results confirm bacteriostatic rather than bactericidal effects and show significant differences $(P<0.05 ; F>9.3)$ between the means of antibacterial activity of extracts of various concentrations in both MIC and MBC in the studied sea cucumber $H$. leucospilota. In the antibacterial assays, the methanol extracts showed significant activity against SEA and MRSA with MICs around $100 \mathrm{mg} / \mathrm{ml}$ (Fig. 1, 2). The highest activity was exhibited with MICs ranging from 100 to $6.25 \mathrm{mg} / \mathrm{ml}$ of methanol extracts against SEB (Fig. 3). In methanol extract, bactericidal activity has been found against SEB and MRSA with MBCs that range around $100 \mu \mathrm{g} / \mathrm{ml}$ (Table 1). In addition, the highest antibacterial activity in the disk diffusion assay was determined in the methanol extract against MRSA (Table 2). Chloroform extracts from the whole body showed antibacterial activity against MRSA, SEA, and SEB with MICs of about $50 \mathrm{mg} / \mathrm{ml}$ (Fig. 4, 5,6). Also, chloroform extracts demonstrate bactericidal activity against SEB in concentrations of about 100 $\mathrm{mg} / \mathrm{ml}$ (Table 1).

Table 1

Antimicrobial activity of whole body of $\mathrm{H}$. leucospilota methanol and chloroform extracts

\begin{tabular}{|llll|}
\hline Staphylococcus aureus & extracts & MIC & MBC \\
\hline MRSA & Methanol & $100 \mathrm{mg} / \mathrm{ml}$ & $100 \mathrm{mg} / \mathrm{ml}$ \\
\cline { 2 - 4 } SEA & $40 \mu \mathrm{g} / \mathrm{mL}$ & $100 \mathrm{mg} / \mathrm{ml}$ & - \\
\cline { 3 - 4 } SEB & & $6.25 \mathrm{mg} / \mathrm{ml}$ & $100 \mathrm{mg} / \mathrm{ml}$ \\
MRSA & Chloroform & $50 \mathrm{mg} / \mathrm{ml}$ & - \\
\cline { 3 - 4 } SEA & $40 \mu \mathrm{g} / \mathrm{mL}$ & $50 \mathrm{mg} / \mathrm{ml}$ & - \\
SEB & & $50 \mathrm{mg} / \mathrm{ml}$ & $100 \mathrm{mg} / \mathrm{ml}$ \\
\hline
\end{tabular}


Table 2

Disk diffusion result

\begin{tabular}{|lllll|}
\hline Staphylococcus aureus & $\begin{array}{l}\text { Chlorofom extract } \\
(\mathbf{4 0} \boldsymbol{\mu g} / \mathrm{mL})\end{array}$ & $\begin{array}{l}\text { Methanol } \\
\text { extract } \\
(\mathbf{4 0} \boldsymbol{\mu g} / \mathrm{mL})\end{array}$ & $\begin{array}{l}\text { Vancomycin } \\
(\mathbf{3 0} \boldsymbol{\mu g} / \mathrm{ml})\end{array}$ & $\begin{array}{l}\text { Clindamycin } \\
(\mathbf{2 5} \boldsymbol{\mu g} / \mathrm{ml})\end{array}$ \\
\hline MRSA & $12(\mathrm{~mm})$ & $14(\mathrm{~mm})$ & $18(\mathrm{~mm})$ & $16(\mathrm{~mm})$ \\
\hline$S E A$ & $9(\mathrm{~mm})$ & $10(\mathrm{~mm})$ & $19(\mathrm{~mm})$ & $18(\mathrm{~mm})$ \\
\hline$S E B$ & $12(\mathrm{~mm})$ & $11(\mathrm{~mm})$ & $18(\mathrm{~mm})$ & $18(\mathrm{~mm})$ \\
\hline
\end{tabular}

\section{Discussion}

In this study, H. leucospilota methanol extracts showed minimum inhibitory towards the tested $\mathrm{S}$. aureus strains MRSA and SEA around $100 \mathrm{mg} / \mathrm{ml}$. Also, the methanol extract has been shown to be efficient against SEB strains with MICs ranging from 6.25 to $100 \mathrm{mg} / \mathrm{ml}$. In addition, the chloroform extract has been efficient against MRSA, SEA, and SEB strains in MICs ranging from $50 \mathrm{mg} / \mathrm{ml}$ to $100 \mathrm{mg} / \mathrm{ml}$ and effective against SEB in MBCs below100 $\mathrm{mg} / \mathrm{ml}$. We detected the highest antibacterial activity in methanol extract with a zone of hindrance of $14 \mathrm{~mm}$ against MRSA. This could be due to the better suitability of methanol as a solvent for the bioactive products generated across different organs in $H$. leucospilota. Microorganisms utilize different means to limit the concentration of antibacterial agents inside cells: decreasing diffusion, increasing efflux or neutralization of the antibacterial agents that may reversibly or non-reversibly render the drug inactive [13]. In most of the studied species of sea cucumbers $[2,22,23]$, either the body walls or the whole bodies were examined. In addition, limited antimicrobial activity of holothurian compounds has been shown under very high concentrations [15]. In tests with methanol and chloroform extracts sampled from various tissues and organs of $\mathrm{H}$. leucospilota, moderate bacteriostatic activity against a few selected species of Gram-negative and Gram-positive bacteria was reported [2]. Nevertheless, bacteriostatic effects were not noted in such high concentrations [15]. In previous studies, it was suggested that the active compound was a lysozyme [18]. In our study, the wholebody extracts of $H$. leucospilota exhibited antimicrobial activities against MRSA, SEA, and SEB, implying various reasons accountable for this observation. Therefore, comprehensive chemical analyses are needed to isolate and purify the active compounds, identify their chemical nature, and evaluate their possible strength for new medicines [15]. Mokhlesi et. al (2011) analyzed methanol, ethyl acetate, and water-methanol extracts taken from the sea cucumbers' body wall on S. aureus, Escherichia coli, and Pseudomonas aeruginosa in the Persian Gulf. However, they did not detect any inhibitory effect on bacteria's growth in the extracts [12]. Farjami and Nematollah (2013) studied the antimicrobial activity of hexane, chloroform, and methanol extracts from the body wall, gonad, and intestine of $H$. leucospilota against $S$. aureus, Bacillus subtilis, and $P$. aeruginosa [24]. They showed that $P$. aeruginosa is the most sensitive one, and the other extracts had an antibacterial effect in specific concentrations on B. subtilis 
and S. aureus. It is currently unclear what explains the differences in our results and the existing literature. Possible reasons include different extraction techniques, different solvents usage, and the studied specimen's ecological conditions.

\section{Conclusion}

Sea cucumbers are well-known for their pharmaceutical and food values due to their producing distinctive natural bioactive compounds. In this study, the whole body of $H$.leucospilota collected from the Persian Gulf showed antibacterial effects against $S$. aureus strains MRSA, SEA, and SEB. Yet, future studies are required to focus on aquaculture such as sea cucumber $H$. leucospilota. Therefore, sustainable development of aquaculture will be met by enhancing the environmental preservation, food health, omission of pollutants, and quality control of production units based on the ecosystem conditions of the fishery.

\section{Declarations}

\section{Data availability}

The data that support the findings of this study are available from the corresponding author upon reasonable request.

\section{Acknowledgment}

N.A. is extremely grateful to Prof. Dr. Jens Rolff for his insightful comments on and editing the paper at various occasions. The usual disclaimer applies.

\section{Author Contributions}

N.A. designed the study and conducted the experimental work, M.M.K. led the statistical analysis with supports from N.A., N.A. wrote the main manuscript text with supports from M.M.K, and All authors reviewed the manuscript.

\section{Competing interests}

The authors declare that they have no conflicts of interest.

\section{References}

1- Suarez-Jimenez, G. M., Burgos-Hernandez, A., \& Ezquerra-Brauer, J. M. Bioactive peptides and depsipeptides with anticancer potential: Sources from marine animals. Marine drugs, 10(5), 963-986 (2012). 
2- Bordbar, S., Anwar, F., \& Saari, N. High-value components and bioactives from sea cucumbers for functional foods-a review. Marine drugs, 9(10), 1761-1805 (2011).

3- Assawasuparerk, K., Rawangchue, T., \& Phonarknguen, R. Scabraside D derived from sea cucumber induces apoptosis and inhibits metastasis via iNOS and STAT-3 expression in human cholangiocarcinoma xenografts. Asian Pacific Journal of Cancer Prevention, 17(4), 2151-2157 (2016).

4- Tian, F. et al. PE, a new sulfated saponin from sea cucumber, exhibits anti-angiogenic and anti-tumor activities in vitro and in vivo. Cancer biology \& therapy, 4(8), 874-882 (2005).

5- Althunibat, O. Y. et al. In vitro antioxidant and antiproliferative activities of three Malaysian sea cucumber species. Eur J Sci Res, 37(3), 376-87 (2009).

6- Han, H., Yi, Y., Xu, Q., La, M., \& Zhang, H. Two new cytotoxic triterpene glycosides from the sea cucumber Holothuria scabra. Planta medica, 75(15), 1608-1612 (2009).

7- Roginsky, A. et al. FRONDANOL®-A5P from the sea cucumber, Cucumaria frondosa induces cell cycle arrest and apoptosis in pancreatic cancer cells. Pancreas, 29(4), 335 (2004).

8- Dabbagh, A. R., Sedaghat, M. R., Rameshi, H., \& Kamrani, E. Breeding and larval rearing of the sea cucumber Holothuria leucospilota Brandt (Holothuria vegabunda Selenka) from the northern Persian Gulf, Iran. SPC Beche-de-mer Information Bulletin, 31, 35-38 (2011).

9- Afkhami, M., Ehsanpour, M., Khazaali, A., Kamrani, E., Mokhlesi, A., \& Darvish Bastami, K. Sea cucumber fisheries of Qeshm Island, Persian Gulf. SPC Beche-de-mer Information Bulletin, 32, 60-61 (2012).

10- Aydın, M., Sevgili, H., Tufan, B., Emre, Y., \& Köse, S. Proximate composition and fatty acid profile of three different fresh and dried commercial sea cucumbers from Turkey. International journal of food science \& technology, 46(3), 500-508 (2011).

11- Pawson, D. L. Phylum echinodermata in Linnaeus Tercentenary: Progress in Invertebrate Taxonomy (ed. Zhang, Z.-Q. \& Shear, W.A.) 1668, 749-764 (Zootaxa, 2007).

12- Mokhlesi, A. et al. Antibacterial, antifungal and cytotoxic activities of Bohadschia marmorata, a sea cucumber from north coastal of Persian Gulf. Pharmacology Online, 3, 1029-1038 (2011).

13- Rinehart, K. L. et al. Marine natural products as sources of antiviral, antimicrobial, and antineoplastic agents. Pure and applied chemistry, 53(4), 795-817 (1981).

14- Bryan, P. J., McClintock, J. B., Watts, S. A., Marion, K. R., \& Hopkins, T. S. Antimicrobial activity of ethanolic extracts of echinoderms from the northern Gulf of Mexico. Echinoderms Through Time, Balkema, Rotterdam, 17-23 (1994). 
15- Adibpour, N., Nasr, F., Nematpour, F., Shakouri, A., \& Ameri, A. Antibacterial and antifungal activity of Holothuria leucospilota isolated from Persian Gulf and Oman Sea. Jundishapur journal of microbiology, 7(1), e8708 10.5812/jjm.8708 (2014).

16- Mamelona, J. et al. Quantification of phenolic contents and antioxidant capacity of Atlantic sea cucumber, Cucumaria frondosa. Food Chemistry, 104(3), 1040-1047 (2007).

17- Gaidi, G., Miyamoto, T., Rustaiyan, A., \& Lacaille-Dubois, M. A. Three New Acylated Triterpene Saponins from Acanthophyllum s quarrosum. Journal of natural products, 64(7), 920-924 (2001).

18- Estrada, A., Katselis, G. S., Laarveld, B., \& Barl, B. Isolation and evaluation of immunological adjuvant activities of saponins from Polygala senega L. Comparative immunology, microbiology and infectious diseases, 23(1), 27-43 (2000).

19- Lorian, V. Antibiotics in laboratory medicine (ed. Lorian, V.) (Lippincott Williams \& Wilkins, 2005).

20- Arfatahery, N., Davoodabadi, A., \& Abedimohtasab, T. Characterization of toxin genes and antimicrobial susceptibility of Staphylococcus aureus isolates in fishery products in Iran. Scientific reports, 6(1), 1-7 (2016).

21- Thornsberry, C., \& Mcdougal, L. K. Successful use of broth microdilution in susceptibility tests for methicillin-resistant (heteroresistant) staphylococci. Journal of clinical microbiology, 18(5), 1084-1091 (1983).

22-Stabili, L., Lassagues, M., \& Pastore, M. Preliminary Study on the Antibacterial Capabilities of Eggs ofParacentrotus lividus (Echinodermata: Echinoidea). Journal of Invertebrate Pathology, 67(2), 180-182 (1996).

23- Ridzwan, B. H., Kaswandi, M. A., Azman, Y., \& Fuad, M. Screening for antibacterial agents in three species of sea cucumbers from coastal areas of Sabah. General Pharmacology, 26(7), 1539-1543 (1995).

24- Farjami, B., Nematollahi, M. A., Moradi, Y., IRAJIAN, G. R., Nazemi, M., Ardebili, A., \& Pournajaf, A. Antibacterial activity of the sea cucumber Holothuria leucospilota. International Journal of Molecular and Clinical Microbiology, 1, 225-230 (2013).

\section{Figures}


OD

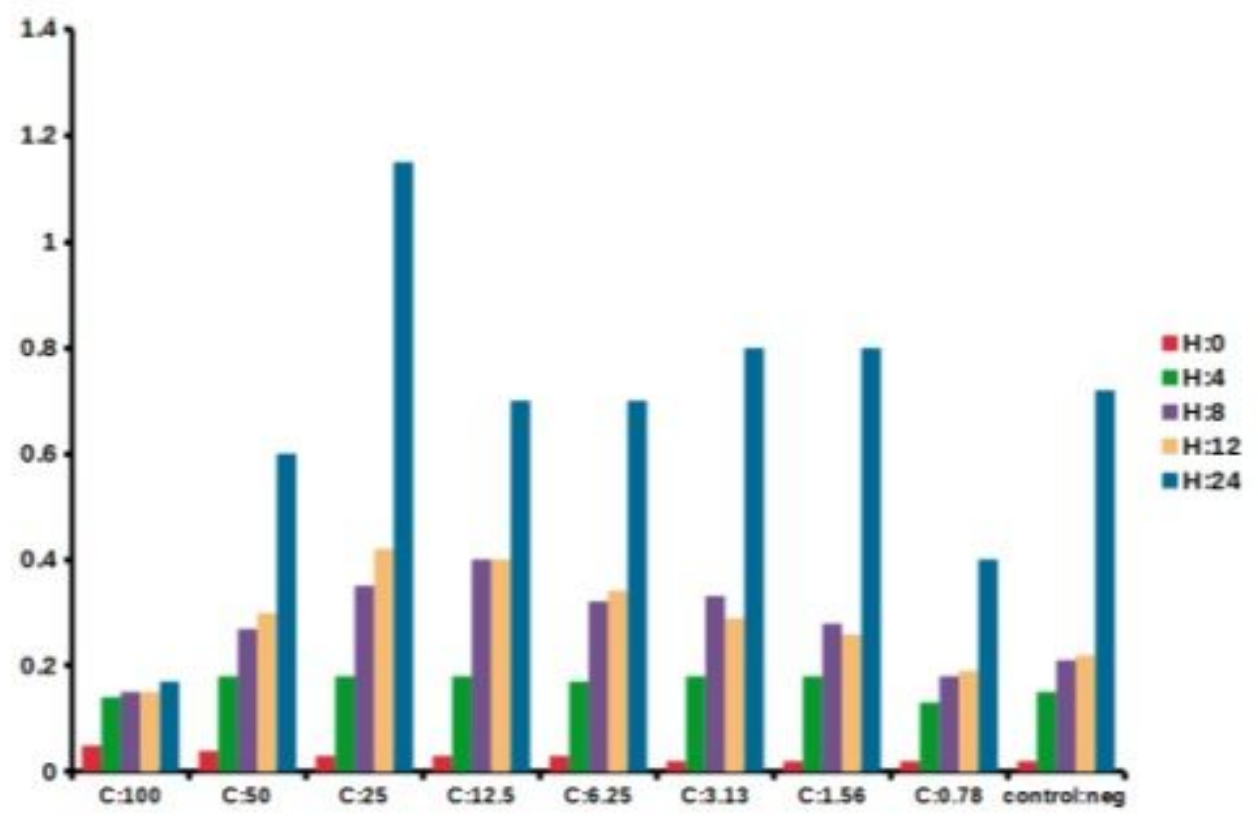

concentration (C) (mg/ml). optical density (OD). hours $(\mathrm{H})$.

\section{Figure 1}

Effect of methanol extracts on Methicillin-resistant S. aureus (MRSA). The effect of methanol extract at different times $(0,4,8,12,24)$ and concentrations. OD of extracts was read by the ELISA reader at $650 \mathrm{~nm}$. concentrations of the extract showed Minimum Inhibitory towards the tested S. aureus strain MRSA. The methanol extract showed significant activity solely against MRSA with MICs of about $100 \mathrm{mg} / \mathrm{ml}$. values bearing different superscripts are significantly different $(p<0.05 ; F>13.3)$. 


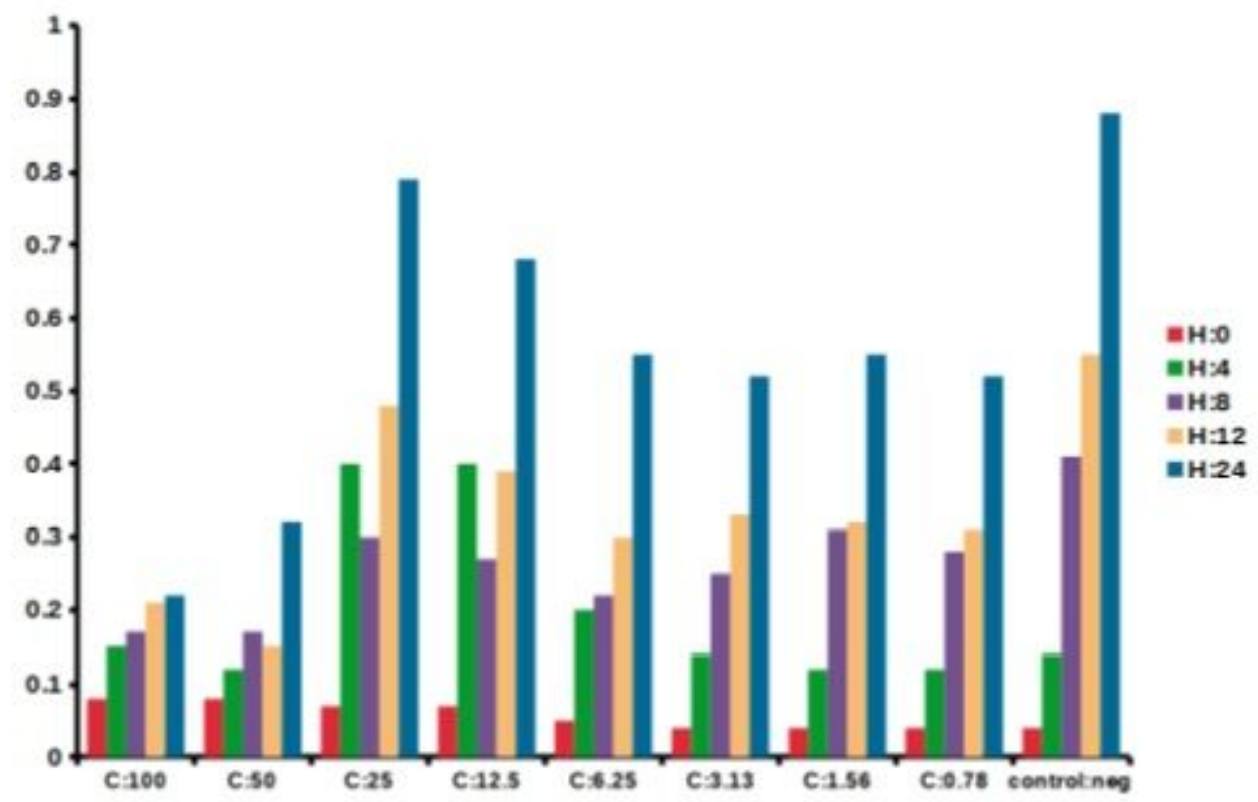

concentration (C) (mg/ml). optical density (OD). hours (H).

\section{Figure 2}

Effect of methanol extracts on S. aureus enterotoxin A (SEA). The effect of methanol extract at different times $(0,4,8,12,24)$ and concentrations. OD of extracts was read by the ELISA reader at $650 \mathrm{~nm}$. concentrations of the extract showed Minimum Inhibitory towards the tested S. aureus strain SEA. The methanol extract showed significant activity solely against SEA with MICs of about $100 \mathrm{mg} / \mathrm{ml}$. values bearing different superscripts are significantly different $(p<0.05 ; F>14.1)$. 
OD

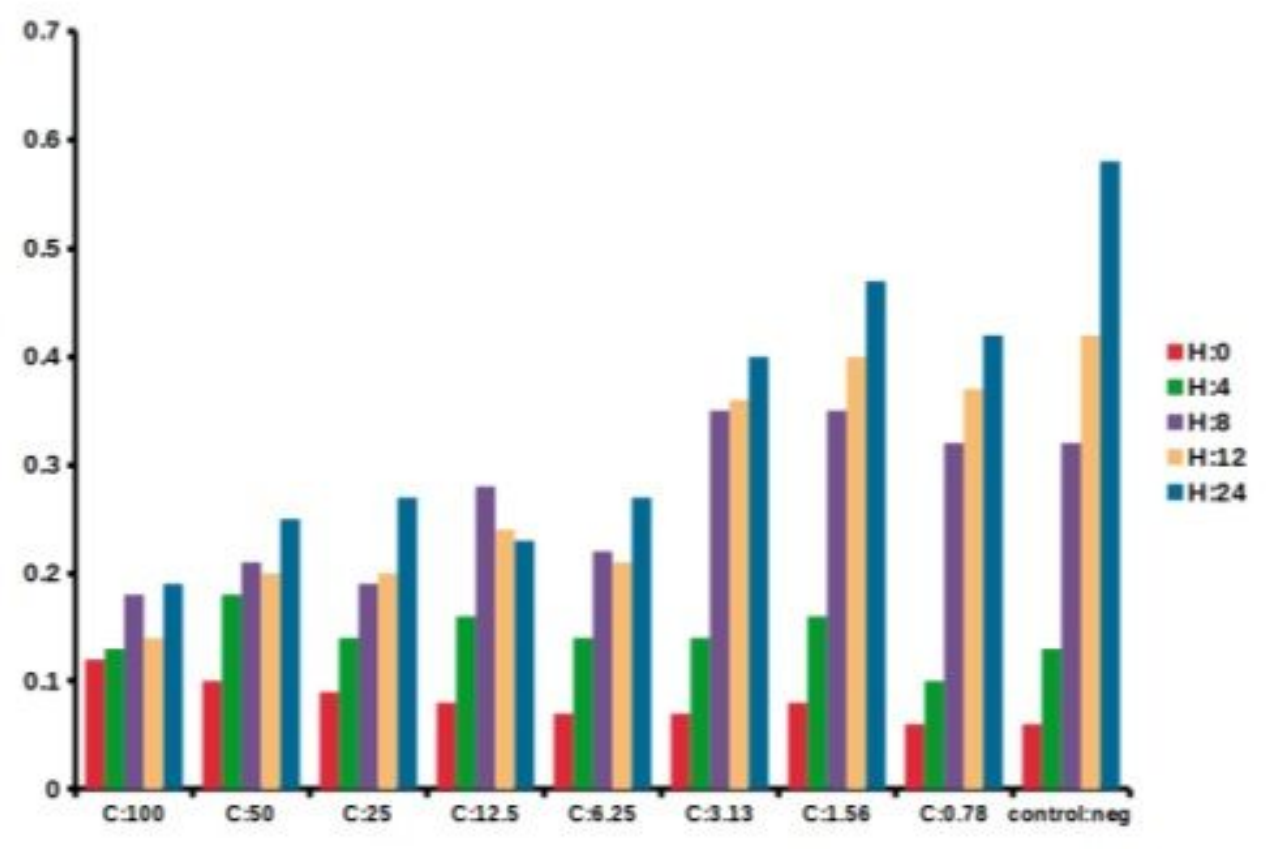

concentration (C) (mg/ml). optical density (OD). hours (H).

Figure 3

Effect of methanol extracts on S. aureus enterotoxin B (SEB). The effect of methanol extract at different times $(0,4,8,12,24)$ and concentrations. OD of extracts was read by the ELISA reader at $650 \mathrm{~nm}$. concentrations of the extract showed Minimum Inhibitory towards the tested S. aureus strain SEB. The methanol extract showed significant activity solely against SEB with MICs ranging from 100 to 0.75 $\mathrm{mg} / \mathrm{ml}$. values bearing different superscripts are significantly different $(p<0.05 ; F>17.0)$. 
$\mathrm{OD}$

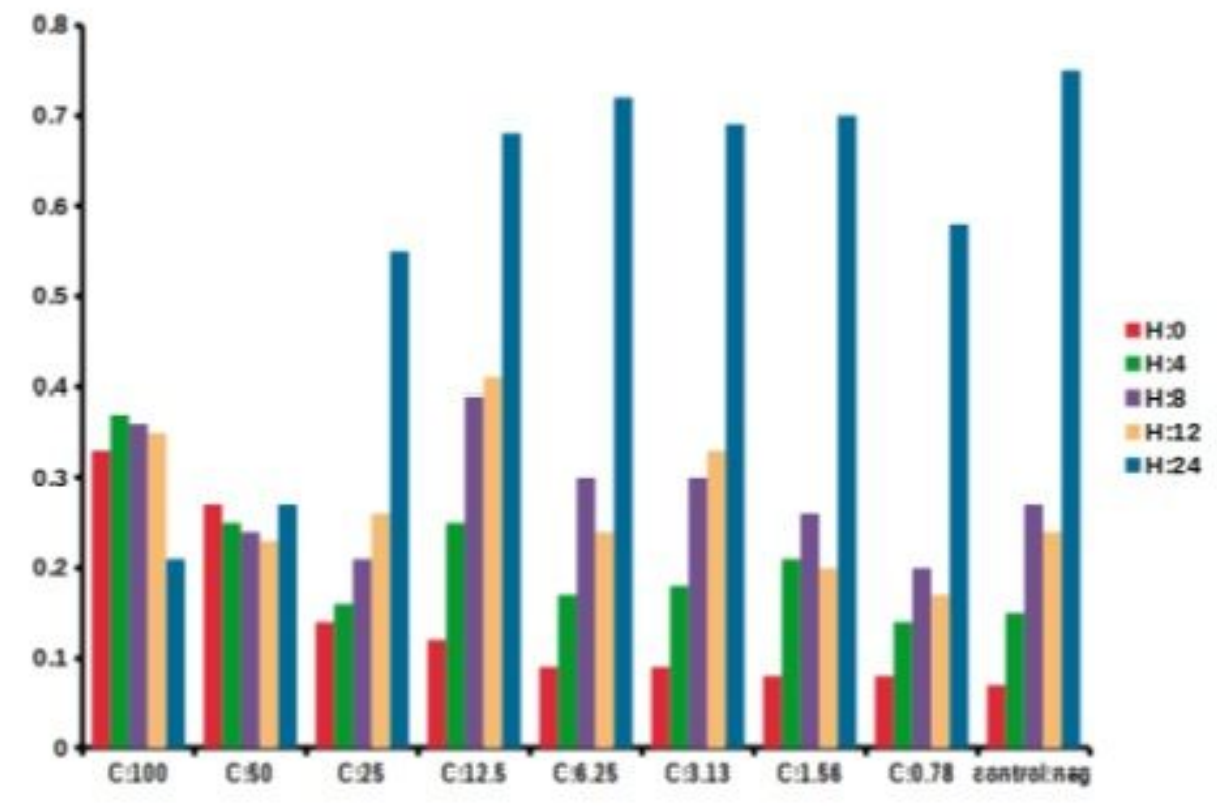

concentration (C) (mg/ml). optical density (OD). hours (H).

\section{Figure 4}

Effect of chloroform extracts on Methicillin-resistant S. aureus (MRSA). The effect of chloroform extract at different times $(0,4,8,12,24)$ and concentrations. OD of extract was read by the ELISA reader at $650 \mathrm{~nm}$. concentrations of the chloroform extract showed Minimum Inhibitory towards the tested S. aureus strain MRSA with MICs of about $50 \mathrm{mg} / \mathrm{ml}$. values bearing different superscripts are different $(p<0.24 ; F>1.4)$. Nonetheless, the model adequacy was accepted after checking the Normality Test, Uncorrolatedness, and Coefficient of Determination (R2=80.6\%). 
OD

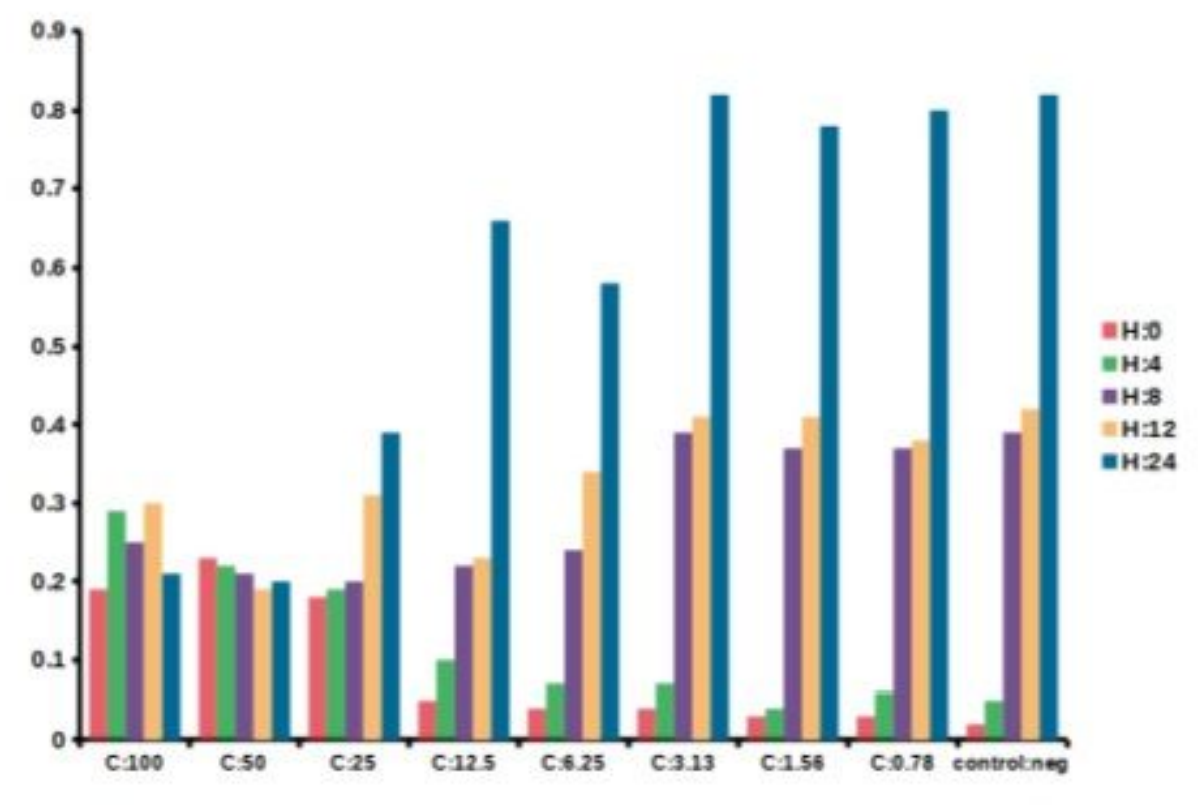

concentration (C) (mg/ml). optical density (OD). hours (H).

Figure 5

Effect of chloroform extracts on S. aureus enterotoxin A (SEA). The effect of chloroform extract at different times $(0,4,8,12,24)$ and concentrations. OD of extract was read by the ELISA reader at $650 \mathrm{~nm}$. concentrations of the chloroform extract showed Minimum Inhibitory towards the tested S. aureus strain with MICs of about $50 \mathrm{mg} / \mathrm{ml}$. values bearing different superscripts are significantly different $(p<0.05$; $\mathrm{F}>13.9)$ 
$\mathrm{OD}$

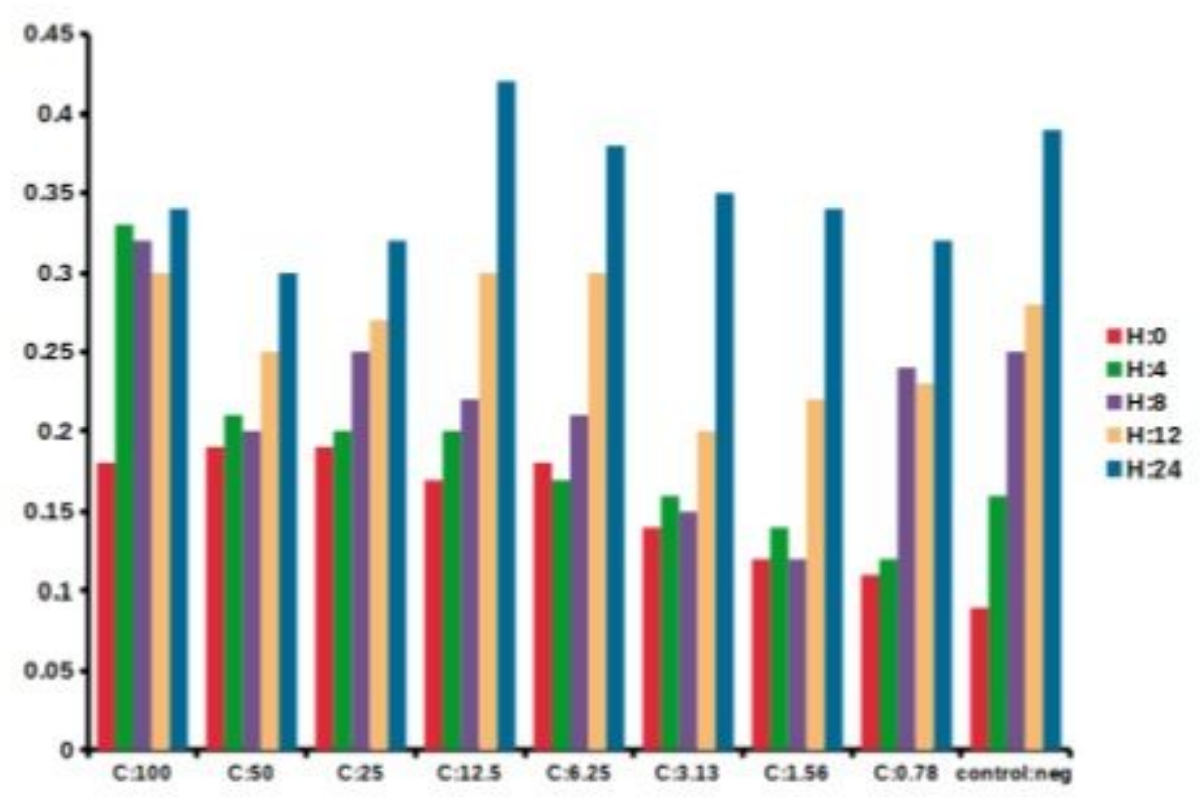

concentration (C) (mg/ml). optical density (OD). hours (H).

Figure 6

Effect of chloroform extracts on S. aureus enterotoxin B (SEB). The effect of chloroform extract at different times $(0,4,8,12,24)$ and concentrations. OD of extract was read by the ELISA reader at $650 \mathrm{~nm}$. concentrations of the chloroform extract showed Minimum Inhibitory towards the tested S. aureus strain SEB, with MICs of about $50 \mathrm{mg} / \mathrm{ml}$. values bearing different superscripts are significantly different $(p<0.05 ; F>9.3)$ 